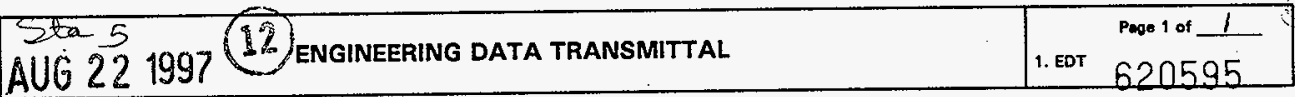

\begin{tabular}{|l|l|}
\hline 2. To: (Receiving Organization) & $\begin{array}{l}\text { 3. From: (Originating Organization) } \\
\text { Engineering Files }\end{array}$ \\
WRAP 1 Engineering \\
\hline W. Proj./Prog./Dept./Div.: & 6. Design Authority/ Design Agent/Cog. \\
W-026/WRAP 1/WMH & RJ Bottenus \\
\hline
\end{tabular}

8. Originator Remarks:

This EDT is to release the Operational Test Report for the Isokinetic Stack Effluent Monitoring System as supporting documentation for the WRAP 1 Facility.

4. Related EDT No.:
N/A
7. Purchase Order No.:
N/A

9. Equip./Component No.:

N/A

10. System/Bldg./Facility:

\section{6-W}

12. Major Assm. Dwg. No.:

$N / A$

13. Permit/Permit Application No.: N/A

14. Required Response Date:

N/A

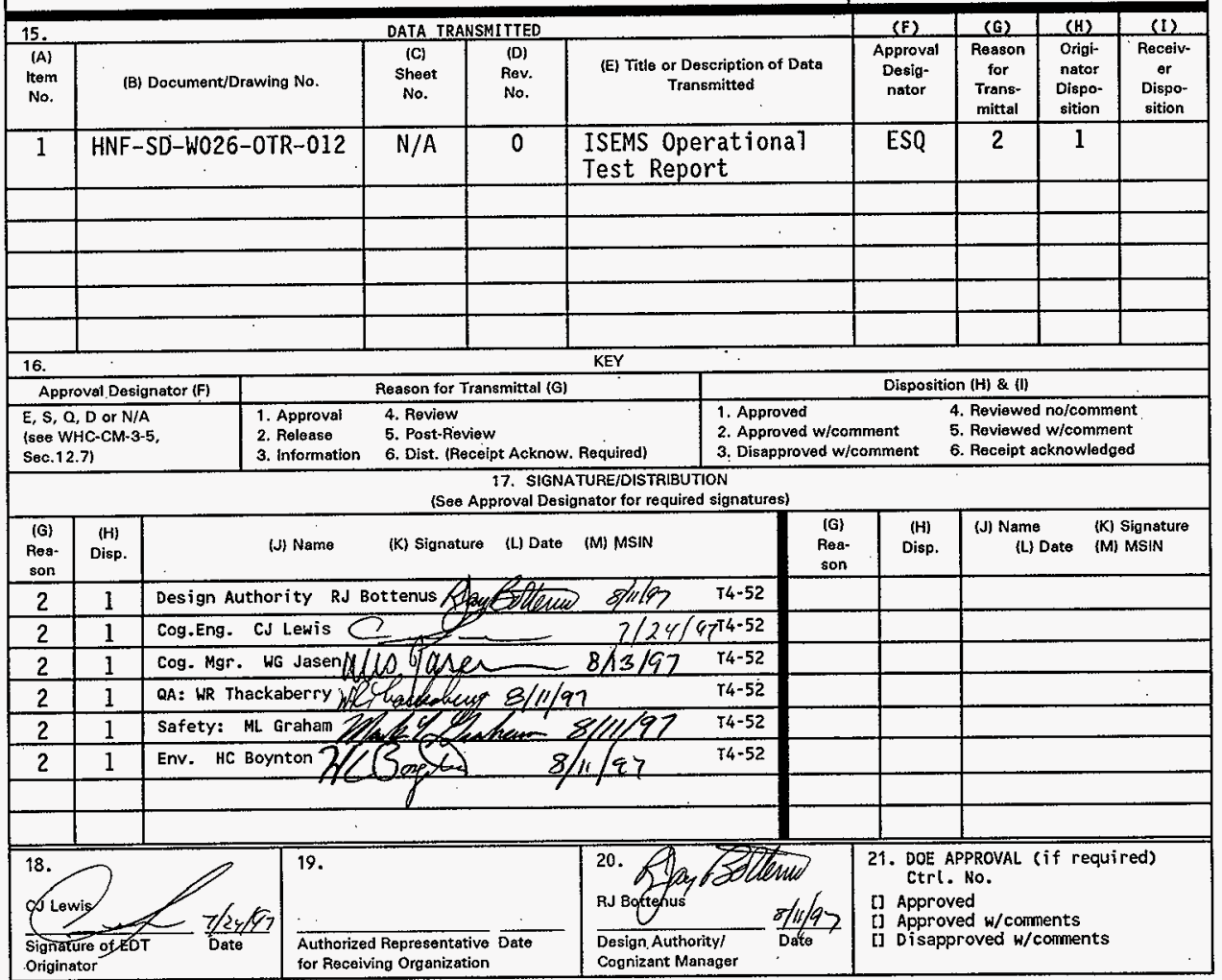




\title{
W-026, Operational Test Report Isokinetic Stack Effluent Monitoring System
}

\author{
CJ Lewis \\ Waste Management Federal Services of Hanford, Inc., Richland, WA 99352 \\ U.S. Department of Energy Contract DE-AC06-96RL13200
}

$\begin{array}{lll}\text { EDT/ECN: } & \text { EDT } 620595 & \text { UC: } 506 \\ \text { Org Code: } & 32620 & \text { Charge Code: }{ }^{A 41 B 3} \\ \text { B\&R Code: } & \text { EW3130020 } & \text { Total Pages: } 7\end{array}$

Key Words: WRAP 1, OTR, Air Emissions

Abstract: This Operational Test Report was performed to assure the Isokinetic Stack Effluent Monitoring System (ISEMS) operates in accordance with system design and specifications.

TRADEMARK DISCLALMER. Reference herein to any specific commercial product, process, or service by trade name, trademark, manufacturer, or otherwise, does not necessarily constitute or imply its endorsement, recommendation, or favoring by the United states Goverment or any agency thereof or its contractors or subcontractors.

Printed in the United States of America. To obtain copies of this document, contact: Document Control Services, P.0. Box 950, Mailstop H6-08, Richland WA 99352, Phone (509) 372-2420; Fax (509) 376-4989.

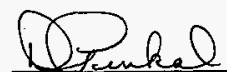

Retease Approval

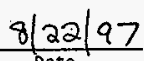

Date

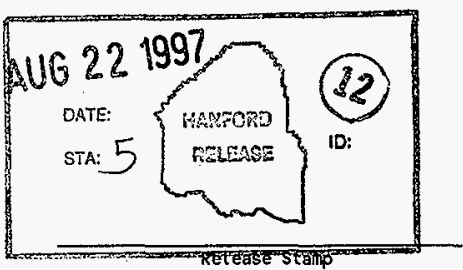




\section{OPERATIONAL TEST REPORT APPROVAL}

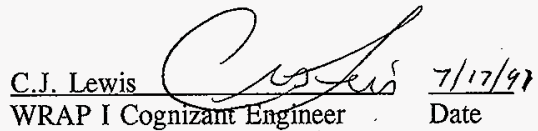

M.F. Hackworth

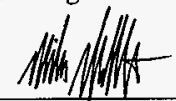

Start-Up Engineer

$\frac{7 / 22 / 97}{\text { Date }}$
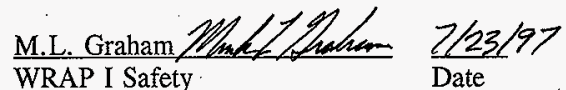

Date

R.B. Swallow $\mathbb{P B} \lambda_{\text {ualow }} 7 / 22 / 97$

WRAP 1 Rad. Control Manager Date
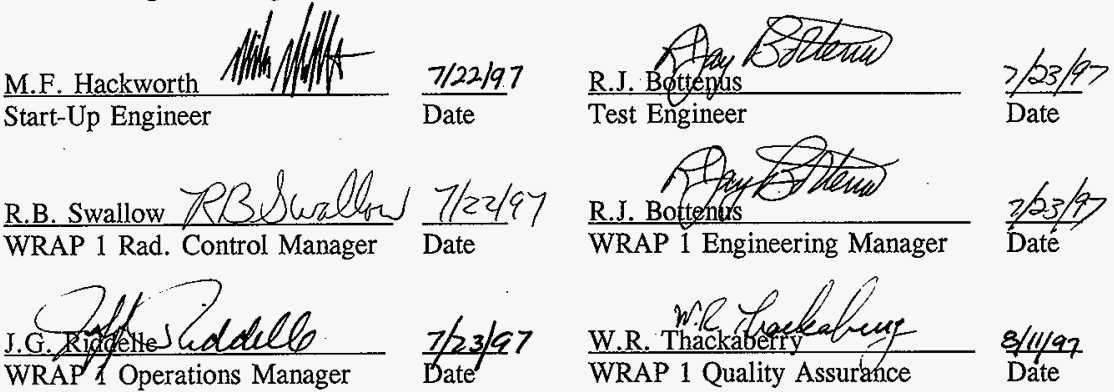

\section{Abstract}

This report documents the testing of the Isokinetic Stack Effluent Monitoring System (ISEMS) associated with phase II start-up of Project W-026, WRAP I.

The ISEMS includes two separate sample extraction loops of the facility exhaust. This exhaust is comprised of primarily glovebox and the glovebox room exhaust. The Record Sample (RS) loop is the non-real-time sample of record for tracking and reporting the facilities annual emissions. The Alpha/Beta Continuous Air Monitor (A/B CAM) loop is the real-time effluent monitoring system which provides current radiation output information. The A/B CAM loop is for alerting the facility of major changes in the composition of the facility exhaust and is not routinely analyzed at the labs or reported as the database of record. However, the CAM filter media will serve as a back up to the record sample media should an anomaly arise or the integrity of the sample is questioned. The system operates isokinetically which means that the sample velocities must be the same as the velocity of the exhaust leaving the stack. Each sample loop utilizes a flow transmitter, PID controller, and an automatic control valve. A Personal Computer station (PC) is utilized for setpoint changes and system trouble and alarm monitoring. 


\section{TABLE OF CONTENTS PAGE}

1.0 INTRODUCTION

2.0 DESCRIPTION OF TEST, TEST METHOD AND TEST EQUIPMENT

3.0 TEST RESULTS

4.0 CONCLUSION AND RECOMMENDATIONS

5.0 REFERENCES

6.0 APPENDIX 


\subsection{INTRODUCTION}

1.1 Organizations

1.1.1 Radiological Control

1.1.2 Operations

1.1.3 Environmental

1.1.4 Engineering

\subsection{Testing Dates}

1.2.1 Testing was performed on $05 / 28 / 97$ to $06 / 28 / 97$.

\subsection{DESCRIPTION OF TEST, TEST METHOD AND TEST EQUIPMENT}

The Primary function of the Operational Test Procedure (OTP) was to test the interface of the ISEMS unit with the Plant Control System (PCS) and other associated peripherals (e.g. annunciator panel, local alarms, etc). Four primary areas of ISEMS operation were tested, each with several subtests. The areas of operation include the following:

\subsection{TEMPERATURE INDICATION - OPERATION TEST}

\subsection{FLOW RATE - OPERATION TEST}

\subsubsection{Stack Total Flow $\left(\mathrm{ft}^{3}\right)$}

2.2.2 Stack Velocity ( $\mathrm{ft} / \mathrm{min})$

2.2.3 Stack Flow Rate $\left(\mathrm{ft}^{3} / \mathrm{min}\right)$

2.2.4 Record Sample Flow Rate )

2.2.5 Alpha/Beta CAM Sample Flow Rate

2.2.6 Confirmation of Isokinetic Sampling

\subsection{ALARM CONDITION - OPERATION TEST}

2.3.1 Low Record Sample Flow Rate Alarm

2.3.2 Alpha/Beta CAM Sample Flow Rate Alarm

2.3.3 Alpha Channel High Radiation Alarm

2.3.4 Beta Channel High Radiation Alarm

2.3.5 CAM Function/Trouble Alarm

\subsection{RADIATION LEVEL - OPERATION TEST}

2.4.1 Alpha Radiation Level Output

2.4.2 Beta Radiation Level Output 


\subsection{SYSTEM RESTART - OPERATION TEST}

2.5.1 Automatic Restart of System with out parameter loss

\subsection{ISEMS OPERATION/INSPECTION PROCEDURE WALK DOWN}

No test equipment was necessary for the test except for NIST traceable radioactive sources (see OTP for serial numbers).

\subsection{TEST RESULTS}

The ISEMS Testing was completed under the direction of the Test Engineer and the guidance of HNFSD-W026-OTP-012.

The temperature operation test was performed by reading the indicated temperature off the stack sensor tray in the morning, midday, and late afternoon. These values were compared to the values indicated on the RTAP screen and local PC values at the corresponding times. The largest amount of difference was less than $1 \mathrm{~F}$ or $1.4 \%$.

Stack Total Flow is the total volume of effluent which has been exhausted through the stack since installation. This flow is displayed on the sensor tray (direct reading from in-stack anemometer), the local PC display, and the RTAP screen. The direct reading off the sensor tray is the total of record, and should be primary indication reported if requested. The PC and the RTAP both displayed similar values, but seemed to increment more erratic than the sensor tray. This was written up as a test exception. After consulting with EG\&G, it was determined that these values are primarily trend information and are calculated values and not directly displayed.

The flow rate tests included demonstrating that both the sample flow rates were not only isokinetic in comparison to the effluent velocity, but that the calibrated flow rates displayed locally were also correspondingly displayed on the RTAP screen. Upon testing the record sample loop, the flow rate discrepancy over a range of values from 1 to $3 \mathrm{scfm}$ never exceeded $\pm 2 \%$. The A/B CAM sample loop was tested over a range of 10 to $25 \mathrm{scfm}$ and the discrepancy between the calibrated local read out and the RTAP display was less than $\pm 3 \%$.

The ISEMS unit has several conditions which cause alarms to annunciate both locally and in the control room's RTAP screen and annunciator panel. Low flow rate alarms were tested by manually throttling the flow of the sample loops below the alarm set points. The A/B CAM low flow alarm anmunciated properly at the ISEMS cabinet, the RTAP screen, and on the annunciator panel. All alarms related to this loop functioned properly. Upon testing the Record Sample loop low flow alarms, a test exception arose. The local alarms and the RTAP alarms annunciated appropriately, but the annunciator panel "Low Flow" alarm did not. The wiring diagrams were reviewed and a missing jumper on the relay board sending the analog signal to the annunciator panel was discovered. A jumper was installed and the results of the retest confirmed resolution of the test exception. 
A CAM function alarm test was completed by disconnecting the alpha and beta detector inputs to the Multilogger at the back of the CAM unit. When the alpha input was disconnected, the PC was unable to access alpha count rate information from the Multilogger and actuated the appropriate alarms locally, on the RTAP, and at the annunciator panel. The same actions occurred when the beta input was disconnected. During this portion of the test, the function alarm would cycle on and off for no apparent reason. A test exception was generated due to the inexplicability of the cyclic behavior.

It was determined that the CAM function and trouble alarms would annunciate when the CAM counts per second were negative or zero, which resulted in the cyclic behavior. Negative and zero counts is not uncommon nor unexpected. The CAM continually subtracts the background radiation value and the radon discrimination factor from the gross counts. Often times this net count would be zero or negative. This causes the CAM function alarm to periodically cycle on and off giving a false alarm. EG\&G rewrote the software code to access the Multiloggers' integral counts and not the net counts. Therefore, the system would not get a zero or negative count, but still would be able to discriminate whether or not a functional problem was occurring with the CAM. Retesting of this alarm condition was successful. Furthermore, as the remainder of the OTP was performed, the CAM function alarm ceased to cycle on and off upon zero and negative counts.

The high alpha and high beta radiation alarms were tested by putting the NIST traceable sources into the CAM filter drawer. The alarm setpoints were then lowered to levels below calibrated activity of the sources. The local, RTAP, and annunciator panel alarms properly actuated respective to the appropriate source introduced into the CAM.

The Multilogger is designed to track and display the alpha and beta radiation levels and send an analog output to the PCS. The PCS then interprets the signal and displays the current levels on the RTAP screen. In testing the ability of the PCS to interpret the analog signal and display the appropriate activity level, a test exception was generated. Even though the Multilogger was measuring and displaying an alpha and a beta activity, the PCS was not receiving any signal from the ISEMS unit. The exception was resolved by tracing the hard wire connections between the flow sensing devices, outputs to the PCS, and the Multilogger. It was discovered that two pair of wires were reversed in polarity. One pair of wires was the signal from the Alpha/Beta sample flow transmitter to the Multilogger. This erroneous flow rate signal prevented the Multilogger from making the appropriate differential calculations. The second pair of wires which were reversed in polarity was from the analog signal out of the Multilogger to the PCS. This was the primary reason for the exception. The wires were properly configured and the electrical drawings were updated. The retest of the alpha and beta radiation levels was successful and the test exception was closed.

The final test was to ensure the parameters (e.g. alarm set points, flow ranges, etc) are not lost upon power failure. The original parameters were printed and power to the system was cut. After five minutes power to the system was restored. Reexamination of the parameters confirmed that the lithium battery back up functioned properly and no data was lost.

As part of the operational testing, WRP1-OP-1213, ISOKINETIC STACK EFFLUENT MONITORING SYSTEM OPERATION/INSPECTION was walked down and redlined. The changes are being made and will be signed and approved through the normal procedure approval cycle. The primary change in the 
WASTE MANAGEMENT FEDERAL SERVICES HANFORD

HNF-SD-W026-OTR-012, Rev. 0

Project W-026, WRAP I

Operational Test Report - ISOKINETIC STACK EFFLUENT MONITORING SYSTEM

procedure was a shift in the method of running detector plateaus and background efficiency counts. The original procedure only had provisions to preform these activities through the PC. However, it was determined to be a more efficient method to run the utilities directly through the Multilogger. The procedure will reflect both capabilities.

\subsection{CONCLUSION AND RECOMMENDATIONS}

The operational testing of the ISEMS unit has been completed and all associated test exceptions have been resolved. All of the alarms are functioning properly. The PCS PLC has been appropriately scaled and the RTAP display of temperature, flow rates, and radiation levels are correct. Changes in these levels match the local readouts and track accordingly. Final electrical system drawing redline changes will be made by EG\&G and turned over to FDH for conversion to H-2 drawings. Final factory calibrations of the flow transmitters is being performed and calibrated spares will be ordered.

\subsection{REFERENCES}

Operational Test Plan - ISOKINETIC STACK EFFLUENT MONITORING SYSTEM

\subsection{APPENDIX}

NOTE - The completed OTP is stored in the facility records and is available upon request from Document Control. 